\title{
The Real Effects of U.S. Banking Deregulation
}

\author{
Philip E. Strahan
}

4 $\mathrm{n}$ the 1970s, commercial banks in the United States faced restrictions on interest rates, both on the deposit and lending sides of their business. They were restricted for the most part to classic financial intermediation-deposit-taking and lending - to the exclusion, for example, of underwriting many corporate securities and insurance products. And banks were limited in the geographical scope of their operations. No state permitted banks headquartered in other states either to open branches or to buy their banks, and many states prohibited or restricted intrastate branching.

Today, almost all of these restrictions have been lifted: Interest rate ceilings on deposits were phased out in the early 1980s; state usury laws have been weakened because banks may now lend anywhere; and limits to banks' ability to engage in other financial activities have been almost completely eliminated, as have restrictions on the geographical scope of banking. As a result, our banking system is now more competitive and more consolidated than everboth vertically and horizontally.

This paper focuses on how one dimension of this broad-based deregulation - the removal of limits on bank entry and expansion-affected economic performance. In a nutshell, the results suggest that this regulatory change was followed by better per formance of the real economy. State economies grew faster and had higher rates of new business formation after this deregulation. At the same time, macroeconomic stability improved. By opening up markets and allowing the banking system to integrate across the nation, deregulation made local economies less sensitive to the fortunes of their local banks.

First, I explain how relaxation of geographical restrictions on bank expansion proceeded historically and why our somewhat unusual history of state-level regulation and deregulation presents an

Philip E. Strahan is an associate professor of finance at the Carroll School of Management, Boston College, and a researcher at the Wharton Financial Institutions Center. He is also a faculty research fellow at the National Bureau of Economic Research. The author thanks David Wheelock for his comments.

(C) 2003, The Federal Reserve Bank of St. Louis.

attractive setting to study how the financial system affects the real economy. I then present evidence that banking deregulation led to substantial and beneficial real effects on our economy. The findings are important for at least two reasons. First, they demonstrate the tight link between "Wall Street" and "Main Street." Finance is not only affected by the fortunes of the industrial sector, but the reverse holds true as well. This mutual dependence highlights the importance of financial regulation not only here in the United States but, perhaps even more critically, in emerging economies without a welldeveloped set of financial markets and institutions. Second, the results support the idea that competition and openness in financial markets are beneficial. This finding is accepted when applied to industrial firms - for most economists, free trade and competition are akin to motherhood-but it is much less accepted when applied to the financial sector.

\section{BANK DEREGULATION AS AN EMPIRICAL LABORATORY}

The evolutionary history of banking regulations in the United States offers researchers a unique opportunity to study the effects of deregulation, particularly those related to restrictions on banks' ability to expand within and across state lines, because regulations were imposed at the state level and because states changed their regulatory restrictions on expansion at different times. Although there was some deregulation of branching restrictions in the $1930 \mathrm{~s}$, most states continued to enforce these policies into the 1970 s. In 1970 , only 12 states allowed unrestricted statewide branching. Between 1970 and 1994, however, 38 states deregulated their restrictions on branching. ${ }^{1}$

In addition to branching limitations within a state, until the 1980s states effectively prohibited cross-state ownership of banks by applying the Douglas Amendment to the 1956 Bank Holding Company (BHC) Act. This amendment prohibited a $\mathrm{BHC}$ from acquiring banks outside the state where

1 Although branching was generally restricted, banking companies could expand in some states by forming multi-bank holding companies. 


\section{Table 1}

\section{Year of State-Level Deregulation of Restrictions on Geographical Expansion}

\begin{tabular}{|c|c|c|c|}
\hline State & $\begin{array}{c}\text { Intrastate branching } \\
\text { via } M \& A\end{array}$ & $\begin{array}{l}\text { Unrestricted intrastate } \\
\text { branching permitted }\end{array}$ & $\begin{array}{c}\text { Interstate banking } \\
\text { permitted }\end{array}$ \\
\hline Alabama & 1981 & 1990 & 1987 \\
\hline Alaska & $<1970$ & $<1970$ & 1982 \\
\hline Arizona & $<1970$ & $<1970$ & 1986 \\
\hline Arkansas & 1994 & $*$ & 1989 \\
\hline California & $<1970$ & $<1970$ & 1987 \\
\hline Colorado & 1991 & $*$ & 1988 \\
\hline Connecticut & 1980 & 1988 & 1983 \\
\hline Delaware & $<1970$ & $<1970$ & 1988 \\
\hline Washington, DC & $<1970$ & $<1970$ & 1985 \\
\hline Florida & 1988 & 1988 & 1985 \\
\hline Georgia & 1983 & * & 1985 \\
\hline Hawaii & 1986 & 1986 & $*$ \\
\hline Idaho & $<1970$ & $<1970$ & 1985 \\
\hline Illinois & 1988 & 1993 & 1986 \\
\hline Indiana & 1989 & 1991 & 1986 \\
\hline lowa & $*$ & $*$ & 1991 \\
\hline Kansas & 1987 & 1990 & 1992 \\
\hline Kentucky & 1990 & $*$ & 1984 \\
\hline Louisiana & 1988 & 1988 & 1987 \\
\hline Maine & 1975 & 1975 & 1978 \\
\hline Maryland & $<1970$ & $<1970$ & 1985 \\
\hline Massachusetts & 1984 & 1984 & 1983 \\
\hline Michigan & 1987 & 1988 & 1986 \\
\hline Minnesota & 1993 & $*$ & 1986 \\
\hline Mississippi & 1986 & 1989 & 1988 \\
\hline Missouri & 1990 & 1990 & 1986 \\
\hline
\end{tabular}

it was headquartered unless the target bank's state permitted such acquisitions. Since states chose to bar such transactions, the amendment effectively prevented interstate banking. Change began in 1978 , when Maine passed a law allowing entry by out-ofstate BHCs if, in return, banks from Maine were allowed to enter those states. (Entry in the case means the ability to buy incumbent banks.) No state reciprocated, however, so the deregulation process remained stalled until 1982, when Alaska and New York passed laws similar to Maine's. State deregulation was nearly complete by 1992 , by which time all states but Hawaii had passed similar laws.

Table 1 notes the years each state relaxed these restrictions on bank branching and interstate banking. The first column presents the year in which each state permitted branching by means of merger and acquisition (M\&A) only. With this form of deregulation, an expansion-minded bank could enter a new market, either by buying an existing bank in that market and folding its operations into the acquirer's existing operations or by buying individual branches of existing banks. The second column reports the year in which each state first permitted unrestricted branching, thereby allowing banks to enter new markets by opening new branches. In most cases, branching by $M \& A$ occurred first, then unrestricted branching deregulation occurred soon 


\section{Table 1 cont'd}

Year of State-Level Deregulation of Restrictions on Geographical Expansion

\begin{tabular}{|c|c|c|c|}
\hline State & $\begin{array}{c}\text { Intrastate branching } \\
\text { via } M \& A\end{array}$ & $\begin{array}{c}\text { Unrestricted intrastate } \\
\text { branching permitted }\end{array}$ & $\begin{array}{c}\text { Interstate banking } \\
\text { permitted }\end{array}$ \\
\hline Montana & 1990 & $*$ & 1993 \\
\hline Nebraska & 1985 & $*$ & 1990 \\
\hline Nevada & $<1970$ & $<1970$ & 1985 \\
\hline New Hampshire & 1987 & 1987 & 1987 \\
\hline New Jersey & 1977 & $*$ & 1986 \\
\hline New Mexico & 1991 & 1991 & 1989 \\
\hline New York & 1976 & 1976 & 1982 \\
\hline North Carolina & $<1970$ & $<1970$ & 1985 \\
\hline North Dakota & 1987 & $*$ & 1991 \\
\hline Ohio & 1979 & 1989 & 1985 \\
\hline Oklahoma & 1988 & $*$ & 1987 \\
\hline Oregon & 1985 & 1985 & 1986 \\
\hline Pennsylvania & 1982 & 1990 & 1986 \\
\hline Rhode Island & $<1970$ & $<1970$ & 1984 \\
\hline South Carolina & $<1970$ & $<1970$ & 1986 \\
\hline South Dakota & $<1970$ & $<1970$ & 1988 \\
\hline Tennessee & 1985 & 1990 & 1985 \\
\hline Texas & 1988 & 1988 & 1987 \\
\hline Utah & 1981 & 1981 & 1984 \\
\hline Vermont & 1970 & 1970 & 1988 \\
\hline Virginia & 1978 & 1987 & 1985 \\
\hline Washington & 1985 & 1985 & 1987 \\
\hline West Virginia & 1987 & 1987 & 1988 \\
\hline Wisconsin & 1990 & 1990 & 1987 \\
\hline Wyoming & 1988 & $*$ & 1987 \\
\hline
\end{tabular}

thereafter. Because these changes usually occurred in quick succession, it is hard to isolate the impact of $M \& A$ branching from the impact of permitting new branches; moreover, it turns out that most banks enter new markets by buying existing banks or branches rather than by building new ones. So, in the empirical analysis I construct a single branching indicator based on the date a state first permitted branching by $M \& A$.

The third column reports the year in which states first entered into an interstate banking agreement with other states. With interstate deregulation, it became possible for an outside banking organiza- tion to acquire a state's incumbent banks. This form of deregulation, however, did not permit these newly acquired banking assets to be folded into the acquirer's banking operations outside the state. Statelevel progress toward interstate banking, therefore, did not lead to interstate branching. In 1994, though, the deregulatory process was completed with passage of the Interstate Banking and Branching Efficiency Act of 1994 (IBBEA), federal legislation that mandated complete interstate banking as of 1997 and encouraged states to permit interstate branching. IBBEA permitted states to opt out of interstate branching, but only Texas and Montana chose to do so. Most 
other states protected their banks by forcing out-ofstate entrants to buy existing branches rather than open new ones.

The staggered timing of state-level action to deregulate both branching and interstate banking restrictions provides an ideal laboratory to explore empirically how these regulatory changes affected banking and the real economy. Because of the crossstate and over-time variation in the regulatory status of different states, both unobserved state differences and aggregate shocks (and any trends) can be fully absorbed with the inclusion of fixed effects, while leaving sufficient variation in the regulatory variables to estimate their effects on state-level financial and real variables. Moreover, by using the state as the relevant unit, the resulting panel data set is balanced because states do not enter or exit the sample. Thus, there is no need to worry about (or attempt to correct for) survivorship biases that can plague attempts to draw inferences from bank-level or firm-level data. ${ }^{2}$

To be concrete, the research method boils down to estimating a regression using observations from a given state and year (state-year) in the following structure:

$$
\begin{aligned}
& y_{s t}=\alpha_{t}+\beta_{s}+\gamma_{1} \text { Branch }_{s t} \\
& +\gamma_{2} \text { Bank }_{s t}+\text { OtherControls }_{s t}+\varepsilon_{s t},
\end{aligned}
$$

where $s$ indexes states, $t$ indexes time, $y_{s t}$ is the dependent variable of interest, $\alpha_{t}$ is a year-specific fixed effect (estimated by including year indicator variables), $\beta_{s}$ is a state-specific fixed effect (estimated by including state indicator variables), Branch $_{s t}$ is an indicator set to 1 after a state permits branching (by means of $M \& A$ ), and $B a n k_{s t}$ is an indicator set to 1 after a state permits interstate banking. Thus, the deregulation indicators equal 1 in all state-years following deregulation, and they equal 0 in all stateyears prior to deregulation. ${ }^{3}$

\section{Endogenous Deregulation?}

Before describing the results, it is worth considering briefly why banking regulations remained static from the 1930 s to the mid-1970s and why they

\footnotetext{
2 These issues are especially important for studies of entry regulations because the competitive shakeout that occurs after regulatory change increases the odds that some banks will not survive.

3 I drop observations during the year of deregulation. In addition, I do not include Delaware and South Dakota in any of the analyses because these states had a unique history due to the growth of the credit card business there.
}

began to change across all states from the 1970s to the early 1990s. Several developments probably contributed. In the mid-1980s, for instance, the Office of the Comptroller of the Currency took advantage of a clause in the 1864 National Bank Act to allow nationally chartered banks to branch freely in those states where savings institutions (savings and loans and savings banks) did not face branching restrictions. The Comptroller's action was instrumental in introducing statewide branching in several southern states. Another impetus behind deregulation may have been the rash of bank and thrift failures in the 1980s, which increased public awareness of the advantages of large, well-diversified banks. As part of the 1982 Garn-St. Germain Act, for example, federal legislators amended the Bank Holding Company Act to allow failed banks and thrifts to be acquired by any BHC, regardless of state laws (Kane, 1996).

More broadly, Economides, Hubbard, and Palia (1996) show that small banks lobbied successfully in the 1930s for both generous deposit insurance and tight limits on branching, despite the objections of large banks. White (1998) shows that the small bank lobby continued its success over the subsequent 40 years by gaining increased levels of deposit insurance coverage all the way up until 1980, when this limit was last raised (to $\$ 100,000$ ). ${ }^{4}$ Thus, the influence of small banks may explain the relative stability of these regulatory institutions from the 1930s through the 1970s.

Kroszner and Strahan (1999) suggest that the emergence of new technologies in both deposittaking and lending that began in the 1970s tipped the balance in the political arena from the traditional beneficiaries of geographical restrictions-small banks-toward more expansion-minded large banks. As evidence, we show that deregulation occurred earlier in states (i) with fewer small banks, (ii) where small banks were financially weak, and (iii) with more small and bank-dependent firms. We also find that where the insurance industry was large, deregulation tended to occur later, particularly when banks could compete in the sale of insurance products. The relative strength of potential winners (large banks and small firms) and losers (small banks and the rival insurance firms) from deregulation can

\footnotetext{
4 As of this writing, an increase in FDIC insurance coverage to $\$ 130,000$ is under debate in Congress at the urging of advocacy groups representing the interests of small, community banks.
} 
therefore explain the timing of branching reform across states. 5

Given these political economy explanations for banking reform, can we interpret the results from equation (1)? The results in Kroszner and Strahan (1999) suggest that aggregate forces such as technological change affected all financial services firms and created increasingly strong pressures for regulatory regime change; however, interest group factors determined the exact timing of when a particular state changed its laws. Thus, a cross-state comparison of state growth or business cycle volatility might be misleading, or at least difficult to interpret. For example, consider comparing states in a single year, say, 1987. If states permitting interstate banking had more large banks than states that did not yet permit interstate banking, it could be that regulation led to structural changes favoring large banks (i.e., regulation caused the structural change). Or it could be that states with more large banks deregulated before states with fewer large banks (i.e., regulation was caused by the cross-state differences in structure).

The estimators reported here are not likely to be affected by the political economy factors. By including the state fixed effects $\left(\beta_{s}\right)$ in the model, all of the cross-sectional variation (such as when a state deregulates) gets removed; coefficients are driven by changes in variables after a state alters its regulations. Persistent differences across states (e.g., those dominated by large vs. small banks) do not affect the results. Instead, we look at how a state's banking structure changes after it deregulates; how its growth performance changes relative to its level before deregulation; and how the volatility of its business cycle changes, again, relative to its volatility prior to regulatory change.

\section{HOW BANKING CHANGED AFTER DEREGULATION}

We can expect deregulation to have had large effects on the real economy only if there were important changes in the structure and efficiency of the banking industry resulting from the reforms. Briefly, the key changes are as follows: Relaxing restrictions on bank expansion led to larger banks operating across a wider geographical area. Increases in local market concentration, however, did not occur. This makes sense because the restrictions

\footnotetext{
5 We also find that the same interest group variables also can explain the voting patterns of legislators in the U.S. House of Representatives on interstate banking deregulation and deposit insurance reform. (See Kroszner and Strahan, 2001.)
}

on branching and interstate banking generally did not apply to local markets, with the exception of a few unit banking states that did not permit branching in any form. Thus, deregulation led banks to enter new markets, but it did not spur banks to consolidate within a local market. ${ }^{6}$

Table 2 documents very briefly the magnitude of some of these changes, including the estimated coefficients on the intrastate branching indicator $\left(\right.$ Branch $\left._{s t}\right)$ and the interstate banking indicator $\left(\right.$ Bank $\left._{s t}\right)$ from the fixed-effects model described in equation (1). In column 1, the dependent variable equals the acquisition rate in a state-year (defined as the total dollar value of assets in banks acquired in a state-year, divided by total banking assets in the state at the beginning of the year). ${ }^{7}$ The results suggest, as expected, that acquisitions increased sharply following interstate banking deregulation. The coefficient implies that the annual acquisition rate rose by 1.64 percentage points after interstate reform - quite a large jump relative to the unconditional mean of 2.77 percent. In contrast, there was no significant increase in bank acquisitions following branching deregulation. Banks tended to expand by purchasing branches of existing banks rather than by acquiring all of the branches and other assets of whole banks, so the acquisition rate of whole banks did not rise. (For details, see Stiroh and Strahan, forthcoming.)

The second column of Table 2 shows that local market concentration did not increase following deregulation despite the increased acquisition activity; if anything, there was a slight drop following interstate banking reform. ${ }^{8}$ Local market concentration equals the deposit Herfindahl-Hirschman Index (HHI), calculated as the deposit-weighted average of the HHIs of the metropolitan statistical areas (MSAs) in a state-year. The HHI for each local market is defined as the sum of squared market shares, where market shares are based on branchlevel deposit data from the Federal Deposit Insurance Corporation's Summary of Deposits data set. To illustrate how this variable is computed, consider a bank (or banking company) that owned 10 branches

\footnotetext{
6 For a comprehensive survey of the literature on financial consolidation, see Berger, Demsetz, and Strahan (1999).

7 An "acquisition" here occurs when ownership of banking assets changes. So, if a BHC buys a bank, or if two unaffiliated banks merge, both would contribute to total assets in acquisitions. But if two banks owned by the same holding company merged, these assets would not be counted.

8 Concentration at the state and national levels has increased substantially, however, in part because of these regulatory changes.
} 


\section{Table 2}

\section{Structural Changes in the Banking Industry Following Deregulation (1994 dollars)}

\begin{tabular}{|c|c|c|c|c|c|}
\hline & \multirow[b]{2}{*}{ Acquisition rate } & \multirow[b]{2}{*}{$\begin{array}{c}\text { Local } \\
\text { deposit HHI }\end{array}$} & \multicolumn{3}{|c|}{ Share of assets in banks with assets } \\
\hline & & & $\begin{array}{l}\text { Less than } \\
\$ 50 \text { million }\end{array}$ & $\begin{array}{c}\$ 50 \text { to } \\
\$ 100 \text { million }\end{array}$ & $\begin{array}{c}\$ 100 \text { to } \\
\$ 500 \text { million }\end{array}$ \\
\hline Post-branching & $\begin{array}{c}0.0031 \\
(0.0062)\end{array}$ & $\begin{array}{c}-9.85 \\
(34.34)\end{array}$ & $\begin{array}{c}-0.016^{*} \\
(0.002)\end{array}$ & $\begin{array}{c}-0.020^{*} \\
(0.003)\end{array}$ & $\begin{array}{c}-0.022^{*} \\
(0.006)\end{array}$ \\
\hline Post-interstate banking & $\begin{array}{c}0.0164^{*} \\
(0.0078)\end{array}$ & $\begin{array}{c}-76.87^{*} \\
(43.13)\end{array}$ & $\begin{array}{c}-0.013^{*} \\
(0.003)\end{array}$ & $\begin{array}{c}-0.005 \\
(0.003)\end{array}$ & $\begin{array}{c}0.004 \\
(0.007)\end{array}$ \\
\hline $\mathrm{N}$ & 849 & 824 & 849 & 849 & 849 \\
\hline Within $\mathrm{R}^{2}$ & 0.1229 & 0.0290 & 0.4644 & 0.3888 & 0.1707 \\
\hline Dependent-variable mean & 0.0277 & 1,913 & 0.089 & 0.103 & 0.232 \\
\hline
\end{tabular}

NOTE: Standard errors in parentheses. The acquisition rate is the dollar value of assets acquired during the state-year divided by beginning-of-period assets in the state-year. The local deposit HHI is the sum of squared market shares for all banking organizations operating within a local market, defined as an MSA. For states with multiple MSAs, we average the HHI across MSAs within the state, weighted by the amount of deposits in the MSA. The model is estimated using a fixed-effects model with both year and state effects. The year of deregulation is dropped. Also, South Dakota and Delaware are dropped. *Statistically significant at the 10 percent level.

within an MSA. This bank's market share (measured in percentage terms) would equal the sum of all of its deposits in those 10 branches, divided by the total deposits held by all bank branches within that MSA, multiplied by 100. For a market with a single bank owning all of the branches, the HHI would equal 10,000, whereas in a perfectly atomistic market the HHI would approach 0.

The last three columns of Table 2 show that the market share of small banks declined following both branching and interstate banking reform. The declines were most pronounced following branching deregulation. For example, the share of assets held by banks with less than $\$ 50$ million in assets (in 1994 dollars) fell by 1.6 percentage points (relative to a mean of 8.9 percent), the share of assets held by banks with assets of $\$ 50$ to $\$ 100$ million fell by 2.0 percentage points (relative to a mean of 10.3 percent), and the share held by banks with assets of $\$ 100$ to $\$ 500$ million fell by 2.2 percentage points (relative to a mean of 23.2 percent). After interstate banking the share of the smallest banks declined while the share of other banks did not change significantly.

Did these structural changes cause meaningful changes in the efficiency of a state's banking industry? In earlier research, Jayaratne and Strahan (1998) report that the banking industry became significantly more efficient following reform. They find that noninterest costs fell, wages fell, and loan losses fell after states deregulated branching. These cost reductions led, in turn, to lower prices on loans (although not on deposits). The mechanism for this better performance seems to be changes in the market shares of banks following deregulation. Prior to regulatory reform, well-run banks faced binding constraints on the markets in which they could operate. When these constraints were lifted, however, assets moved toward the better-run banks as they gained the opportunity to acquire market share. ${ }^{9}$

The beneficial dynamic effects of competition following deregulation can be seen graphically in Figures 1 through $3 .{ }^{10}$ Figure 1 simply plots the correlation between a bank's profit rate (return on equity [ROE]) and its subsequent asset growth. We find that this correlation is low during the late 1970s, when the better banks were constrained by regulations, then rose sharply during the period of regulatory change - the period when better banks were gobbling up market share - and fell back during the 1990s. The figure illustrates, somewhat crudely, the dynamic effects of deregulation.

Figures 2 and 3 show the outcome of these dynamics by plotting the average market share of banks with above-median profits, averaged across states, after first separating them into three groups:

\footnotetext{
9 Hubbard and Palia (1995) also show that management compensation became more sensitive to performance after deregulation.

10 These figures are taken from Stiroh and Strahan (forthcoming).
} 


\section{Figure 1}

Correlation of Performance and Asset Growth

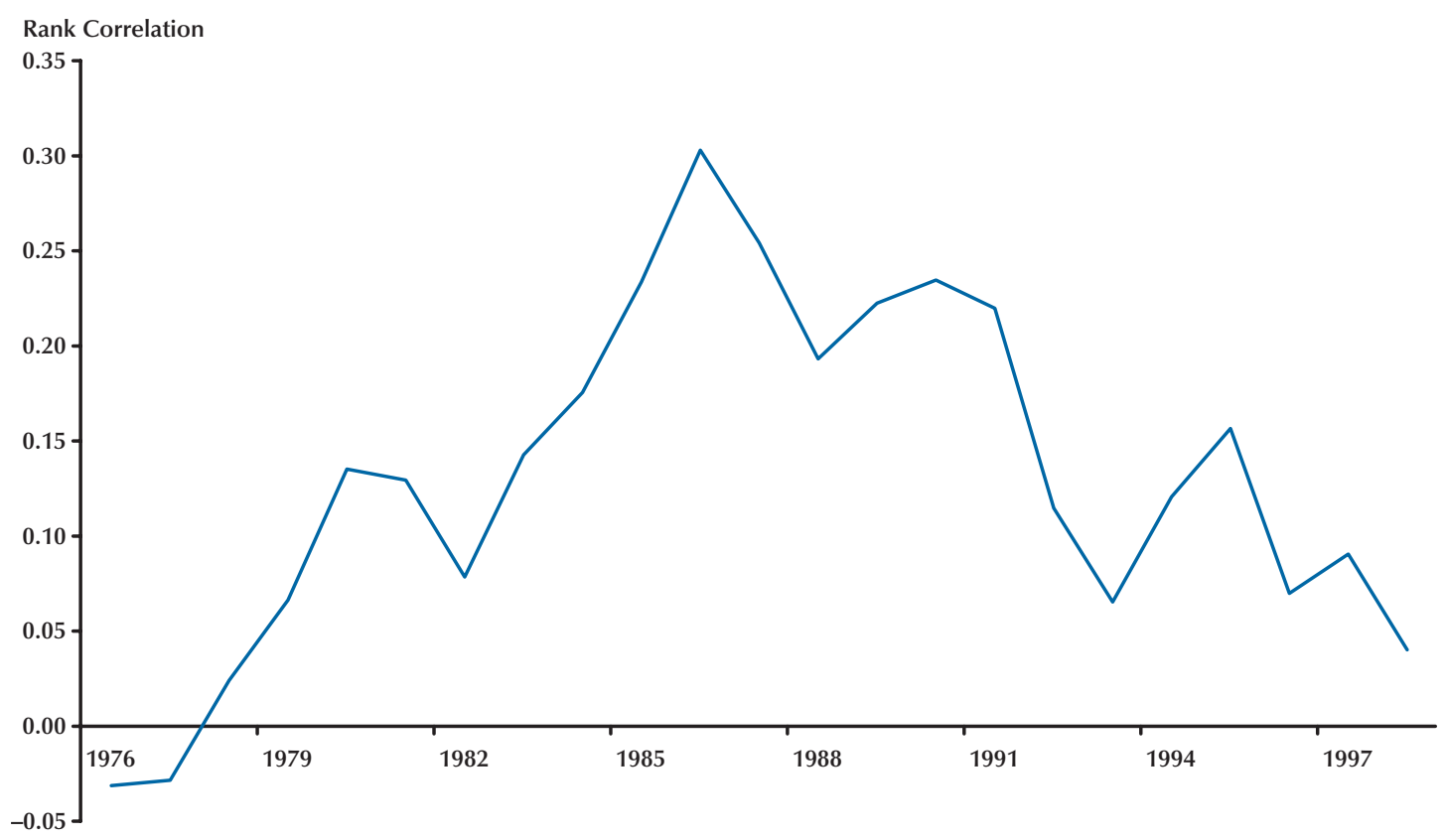

NOTE: Plot of the Spearman rank correlation for each year between a bank's ROE in year ${ }^{t-1}$ (normalized relative to the economy average) and the change in the economywide share of the bank's assets from year ${ }^{t-1}$ to $^{t}$. Correlations include only banks that survive for two consecutive years.

(i) states that have permitted branching since the 1930 s or before (12 states); (ii) states that limited branching (23 states); and (iii) the unit banking states that did not permit any form of branching (16 states). The figures illustrate the detrimental effects of these constraining regulations. For example, in unit banking states, the higher-profit banks typically held 50 percent or less of the assets in a state; after those states relaxed their regulations, however, these better banks' share rose to 65 to 75 percent of the state's assets. States that limited but did not prohibit branching experienced qualitatively similar effects following deregulation, although these effects were somewhat smaller.

\section{THE REAL EFFECTS OF DEREGULATION}

Did the beneficial changes in banking have quantitatively important effects on the real economy? The answer to this question is important not only for helping us gain an understanding of what has happened in the United States, but also for considering how banking systems across the world ought to be structured and regulated. In recent years, a grow- ing number of researchers have studied how different financial regulatory regimes across countries affected financial stability and economic performance. For example, Rajan and Zingales (1998) and Cetorelli and Gambera (2001) test how differences in financial development and banking structure affected growth across different industries. DemirgüçKunt, Levine, and Min (1998) find that banks perform better in countries that are open to foreign entry. Most recently, Barth, Caprio, and Levine (2002) document how various dimensions of banking laws and regulations-e.g., restrictions on bank activities, restrictions on entry, capital adequacy regulations, deposit insurance, supervision and regulation of banks, and government ownership of banks - vary across the world and relate these differences to measures of economic performance and stability.

While the cross-country approach has much to teach us, one of the difficulties inherent in such studies is that many kinds of policy regimes tend to go together. For example, La Porta, Lopez-de-Silanes, and Shleifer (2002) find that government ownership of banks tends to occur in countries with substantial corruption and poor long-run growth performance. 


\section{Figure 2}

\section{Market Share of High-ROE Banks: Unit Banking States vs. Longstanding Branching States}

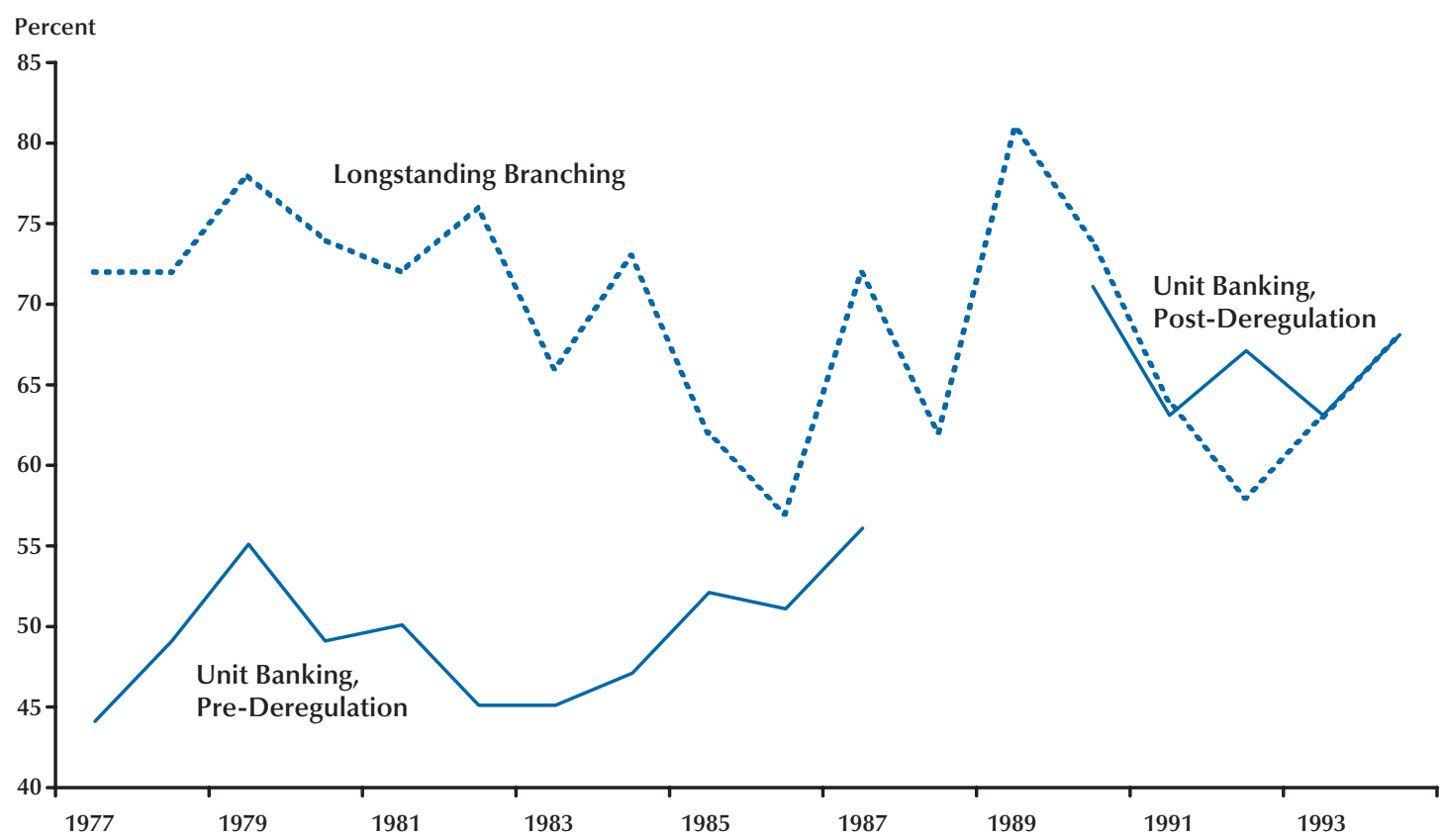

NOTE: Each line represents the market share of banks with above-median ROE, averaged across each type of state. If there are fewer than $\mathbf{1 0}$ states for a particular type in a given year, we do not report the result.

Similarly, Djankov et al. (2002) find that entry regulations also tend to be most prevalent in countries with corrupt political institutions. Thus, it becomes difficult in cross-country studies to determine what specific factor matters; for example, is entry regulation bad, or does it simply proxy for other sorts of government constraints that can be overcome only through bribery?

As noted above, our focus is on the U.S. experience; the relative homogeneity in the economic and legal infrastructure across states presents a strong advantage from an empirical standpoint because the many "invisible" barriers to effective contracting and economic performance are either not present or do not vary substantially across states. Having said that, the hope of this researcher is that the conclusions drawn for the U.S. states will carry over to other environments, such as emerging economies. I will focus specifically on three questions. First, what were the effects of banking reform on states' growth performance? Second, what were the effects of reform on entrepreneurial activity? Third, how did reform affect state-level business cycle stability?

\section{Growth Effects}

Joseph Schumpeter (1969) argued in the early part of the 20th century that efficient financial systems promote innovations; hence, better finance leads to faster growth. On the other hand, Joan Robinson (1952) believed that the causality was reversed; economies with good growth prospects develop institutions to provide the funds necessary to support those good prospects. In other words, the economy leads and finance follows. Recent theoretical developments have fleshed out two potential causal links from financial systems to growth. Financial markets can matter either by affecting the volume of savings available to finance investment or by increasing the productivity (or quality) of that investment. These theories show that an improvement in financial market efficiency can act as a lubricant to the engine of economic growth, allowing that engine to run faster.

Empirical research in recent years has increasingly provided support for the Schumpterian view that financial market development can play an important causal role in driving long-run growth. 


\section{Figure 3}

\section{Market Share of High-ROE Banks: Limited Branching States vs. Longstanding Branching States}

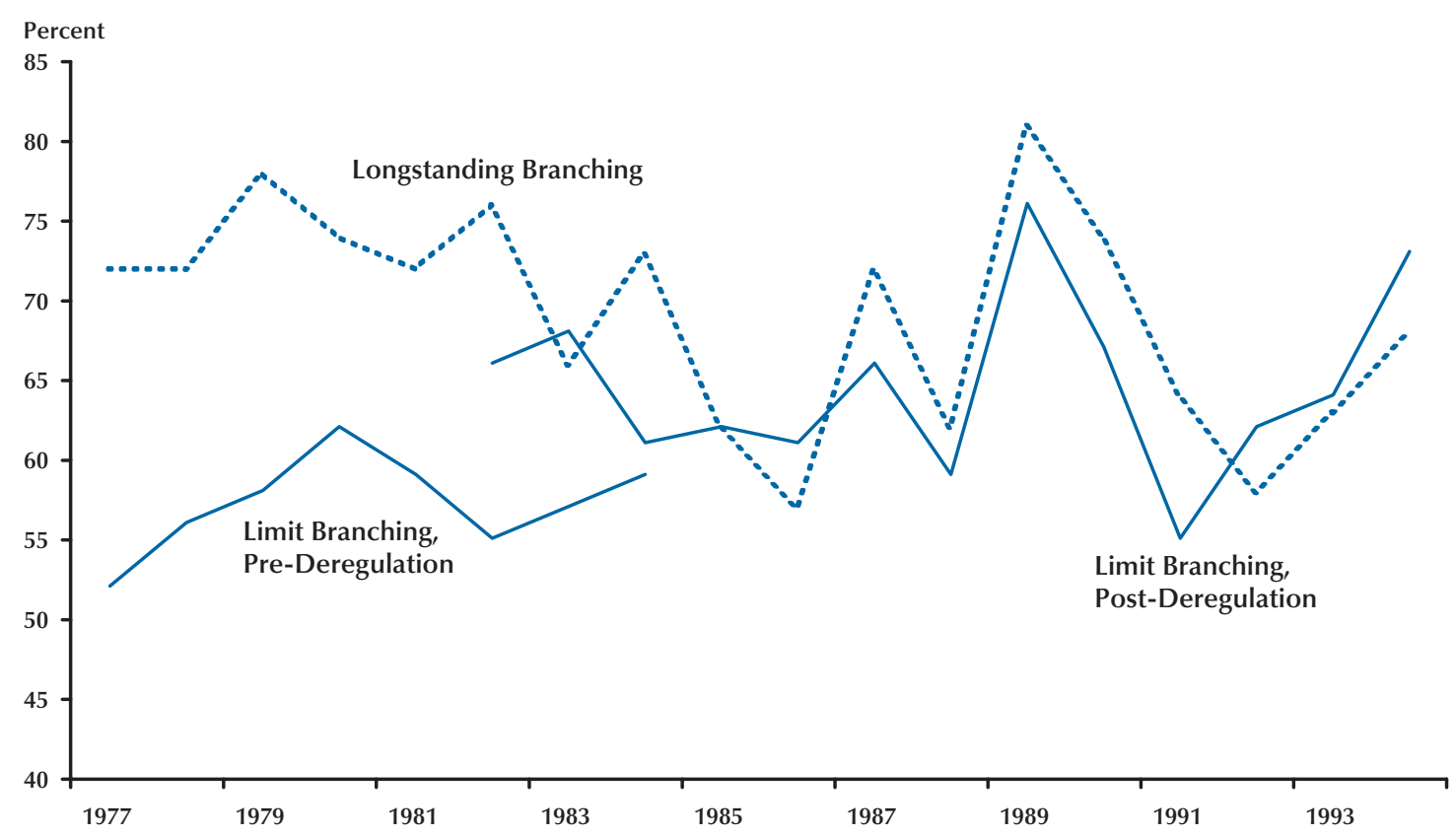

NOTE: Each line represents the market share of banks with above-median ROE, averaged across each type of state. If there are fewer than $\mathbf{1 0}$ states for a particular type in a given year, we do not report the result.

For example, King and Levine (1993) demonstrated that the size and depth of an economy's financial system is positively correlated with its future growth in per capita, real income. While this evidence is appealing, it can not rule out the possibility that financial development and growth are simultaneously driven by a common factor not controlled in the empirical analysis. Rajan and Zingales (1998) and Cetorelli and Gambera (2001) attempt to answer this criticism by exploiting cross-industry differences in financial dependence. They show that in countries with well-developed financial markets, industries that require more external finance grow faster than "cash cow" industries that can finance investment with internally generated funds. ${ }^{11}$ Levine, Loayza,

${ }^{11}$ Cetorelli $(2001,2003)$ attempts to gain a better understanding of the channels through which better finance can affect economic performance. He shows that countries with concentrated banking sectors tend to have more concentrated industrial sectors, particularly in those sectors where external finance is important. Petersen and Rajan (1995) find that small U.S. firms in concentrated local banking markets borrow on better terms than small firms in less-concentrated markets, and Bonaccorsi di Patti and Dell'Ariccia (2001) find that banking concentration in Italy helps foster creation of new firms. and Beck (2000) attempt to establish a causal link from finance to growth by using preexisting legal differences across countries as instruments for the development of the banking system; they show that the exogenous component of banking development is positively related to growth performance.

Another way to establish that better finance (or, specifically, better banking) can lead to faster growth is to find policy changes that lead to more efficient finance (banking) and see how the economy responds. ${ }^{12}$ Bekaert, Harvey, and Lundblad (2003) do this for equity markets, showing that economic growth sped up after liberalization. In our earlier work, Jayaratne and Strahan (1996), we study statelevel branching deregulation and find that this improvement in banking market openness spurred faster economic growth. ${ }^{13}$ Using data from 1972 to 1992, we estimated the change in economic performance before and after deregulation and found that

\footnotetext{
${ }^{12}$ For a comprehensive review, see Levine (2003).

13 More recently, Collender and Shaffer (2002) explore how other aspects of banking structure affect economic growth.
} 


\section{Table 3}

\section{Summary Statistics for State-Level Characteristics}

\begin{tabular}{llc} 
& Mean & Standard deviation \\
\hline Real per capita income growth & 0.0144 & 0.0279 \\
New incorporations per 1000 people living in the state & 2.50 & 1.41 \\
Growth in new incorporations per capita & 0.0206 & 0.1093 \\
Volatility of real per capita growth & 0.0126 & 0.0138 \\
Volatility of growth in new incorporations & 0.0656 & 0.0732 \\
Growth in bank capital & 0.0897 & 0.0842 \\
Share of employment in mining & 0.0128 & 0.0177 \\
Share of employment in construction & 0.0478 & 0.0146 \\
Share of employment in manufacturing & 0.1946 & 0.1124 \\
Share of employment in transportation & 0.0549 & 0.0119 \\
Share of employment in trade & 0.2288 & 0.0377 \\
Share of employment in finance & 0.0533 & 0.0131 \\
Share of employment in services & 0.2192 & 0.0600
\end{tabular}

NOTE: These statistics are calculated using state-year observations. All data except bank capital growth are from the Bureau of Economic Analysis, U.S. Department of Commerce. Bank capital growth equals the change in all capital at banks headquartered in a given state-year (from the Reports of Income and Condition).

annual growth rates accelerated by $1 / 2$ to 1 percentage point. In that study, we worked hard to rule out other interpretations of the finding. For example, we showed that states did not deregulate their economies in anticipation of future good growth prospects. We also found no other concomitant policy changes that could account for the result and no consistent political changes, such as a change in the party controlling the state government, around the time of deregulation.

Below, I reestimate this growth model using a slightly different sample period (1976 to 1996) and include some additional control variables. Table 3 reports summary statistics for the growth measure, which equals the real annual growth rate in per capita state-level personal income. ${ }^{14}$ The personal income data are reported by the Bureau of Economic Analysis and converted to constant dollars using the consumer price index. Over the sample period, real personal income grew at an annual rate of slightly less than 1.5 percent. The standard deviation of the growth rates equals 2.79 percent, with a mini-

\footnotetext{
14 Jayaratne and Strahan (1996) also considered the growth in gross state product, which treats income from capital in a slightly different way from the personal income series. The results, however, were very similar across these two dependent variables.
}

mum of about -15 percent (in North Dakota in 1980) and a maximum of about +17 percent (again in North Dakota in 1978). Overall there is clearly more variability in year-to-year growth rates for small states such as North Dakota, but in Jayaratne and Strahan (1996) we were careful to rule out the possibility that the growth increases were driven by a few of these small states. In the interest of brevity, I will not report these tests here. ${ }^{15}$

Table 4 reports the results of the growth regressions, which include the two banking reform indicator variables, the state and time fixed effects, and a set of variables controlling for the share of employment in each state coming from eight one-digit SIC industries. These share variables account for the possibility that different sectors exhibit different levels of average growth. ${ }^{16}$

\footnotetext{
15 Specifically, we showed that the results remain significant using a weighted least-squares model, where the weights were proportional to state size. In addition, we showed that among the 35 states that deregulated their branching restrictions after 1972, all but 6 experienced an increase in growth after the regulatory changes.

${ }^{16}$ In the regressions the shares sum to 1 , so one of the eight groups must be omitted. In all regressions, the omitted category is the share of employment in the government sector. Hence, all of the coefficients measure the effect of increasing the employment share in the sector relative to the government sector.
} 


\section{Table 4}

Panel Regression of State Growth in Real, Per Capita Income on Banking Deregulation and Employment Share Variables

Dependent variable: growth in real per capita state income

\begin{tabular}{|c|c|c|c|c|}
\hline Post-branching & $\begin{array}{c}0.0056^{*} \\
(0.0024)\end{array}$ & $\begin{array}{c}0.0051^{*} \\
(0.0028)\end{array}$ & $\begin{array}{c}0.0068^{*} \\
(0.0025)\end{array}$ & $\begin{array}{c}0.0066^{*} \\
(0.0025)\end{array}$ \\
\hline Indicator for $5+$ years after branching & - & $\begin{array}{c}-0.0029 \\
(0.0025)\end{array}$ & - & $\begin{array}{c}0.0007 \\
(0.0025)\end{array}$ \\
\hline Indicator for 5 years leading up to branching & - & $\begin{array}{c}-0.0016 \\
(0.0026)\end{array}$ & - & $\begin{array}{c}-0.0001 \\
(0.0027)\end{array}$ \\
\hline Post-interstate banking & $\begin{array}{c}0.0048 \\
(0.0031)\end{array}$ & $\begin{array}{c}0.0049 \\
(0.0031)\end{array}$ & $\begin{array}{c}0.0015 \\
(0.0033)\end{array}$ & $\begin{array}{c}0.0014 \\
(0.0033)\end{array}$ \\
\hline Share of employment in mining & - & - & $\begin{array}{c}0.40^{*} \\
(0.13)\end{array}$ & $\begin{array}{c}0.40^{*} \\
(0.13)\end{array}$ \\
\hline Share of employment in construction & - & - & $\begin{array}{c}0.48^{*} \\
(0.10)\end{array}$ & $\begin{array}{c}0.48^{*} \\
(0.10)\end{array}$ \\
\hline Share of employment in manufacturing & - & - & $\begin{array}{c}0.33^{*} \\
(0.10)\end{array}$ & $\begin{array}{c}0.33^{*} \\
(0.10)\end{array}$ \\
\hline Share of employment in transportation & - & - & $\begin{array}{c}0.63 \\
(0.29)\end{array}$ & $\begin{array}{c}0.63^{*} \\
(0.29)\end{array}$ \\
\hline Share of employment in trade & - & - & $\begin{array}{c}0.04 \\
(0.15)\end{array}$ & $\begin{array}{c}0.04 \\
(0.15)\end{array}$ \\
\hline Share of employment in finance & - & - & $\begin{array}{c}-0.88^{*} \\
(0.29)\end{array}$ & $\begin{array}{c}-0.88^{*} \\
(0.29)\end{array}$ \\
\hline Share of employment in services & - & - & $\begin{array}{c}0.15 \\
(0.12)\end{array}$ & $\begin{array}{c}0.14 \\
(0.12)\end{array}$ \\
\hline $\mathrm{N}$ & 949 & 949 & 890 & 890 \\
\hline Within $\mathrm{R}^{2}$ & 0.5016 & 0.5025 & 0.5485 & 0.5486 \\
\hline
\end{tabular}

NOTE: Standard errors in parentheses. These regressions are estimated using a fixed-effects model with both year and state effects. The year of deregulation is dropped. Also, South Dakota and Delaware are dropped. * Statistically significant at the 10 percent level.

The results in column 1 suggest that average growth accelerated by about 0.56 percentage points following branching reform; following interstate banking reform the point estimate is only slightly lower ( 0.48 percentage points), but it loses statistical significance. ${ }^{17}$ In columns 2 and 4 of Table 4 , I test whether these growth effects reflect either a temporary growth surge just after deregulation or a temporary growth recession just before deregulation. In

\footnotetext{
${ }^{17}$ Because most states permitted interstate banking during the middle of the 1980s, there is much less variation to exploit in the regressions once state and year fixed effects are included. Hence, the standard error of the interstate banking indicator tends to be larger than the standard error on the branching reform indicator.
}

these specifications, I add two additional indicator variables; the first equals 1 starting five years after branching reform, and the second equals 1 during the five-year period leading up to branching reform. The first additional indicator allows us to test whether the growth increases were temporary, since this additional indicator would have a negative and statistically significant coefficient under this hypothesis. (The long-run effect is estimated by summing the two coefficients.) Since this additional variable does not enter the regression with a significant effect, the evidence suggests that the growth effects are permanent. Of course, the amount of time that has elapsed since the end of the deregulatory phase has 
not been long-less than ten years in this data setso these conclusions must be made cautiously.

Freeman (2002) suggests that states deregulated their restrictions on branching during periods following abnormally low (below trend) economic growth. He finds that dropping the observations just prior to deregulation substantially reduces the measured impact of branching reform on growth. Dropping these observations, however, reduces the power of the test by making it harder to pin down the annual business cycle shocks (the year fixed effects). The specifications in columns 2 and 4 of Table 4 , with the pre- and post-deregulation indicators, effectively leave these observations in the sample but allow the growth rates to vary systematically during the years surrounding regulatory change. These results provide very weak evidence that growth was lower leading up to deregulation; the coefficient equals -0.16 percent (not statistically significant) in column 2 of Table 4 (and, effectively, 0 in column 4). Moreover, including these indicators does not lead to a substantively important change in the estimated growth effect of branching reform.

In the last two columns of Table 4, I introduce the employment share variables. These results suggest that mining, construction, manufacturing, and transportation are associated with relatively faster growth than the other sectors. Most important for the purposes here, however, is that the conclusions remain the same. The effect of branching deregulation gets somewhat larger when the share variables are added to the model. Moreover, the indicator equal to 1 during the years starting five years after reform becomes positive, although as before we cannot reject the hypothesis that its coefficient equals 0.18

\section{Effects on Entrepreneurs}

The results so far suggest that growth accelerated after deregulation. But following the logic of Rajan and Zingales, just as cash-constrained firms benefited most from financial development, bankdependent firms ought to have benefited the most

\footnotetext{
18 A quick look at Table 1 suggests that the timing of state deregulation was clustered by region. Thus, one concern with the growth acceleration may be that it is picking up a regional business cycle effect, rather than an increase in growth that can be tied to state-level branching reform. To rule out this possibility, Jayaratne and Strahan (1996) introduce four sets of year indicators, one for each of four broad regions, to control for potential regional business cycles. Introducing these additional controls reduces the growth acceleration by about one third (i.e., the coefficient on the branching deregulation indicator), but it remains statistically significant at the 5 percent level.
}

from the banking deregulation and associated improvements in finance. Entrepreneurs or potential entrepreneurs are likely to be highly dependent on banks and other financial markets because they have not had the opportunity (yet) to generate cash flow that can support investment. Indeed, Schumpeter (1969) himself emphasized the role of financial markets in getting funds to young firms as a key channel through which finance can affect long-run growth. To test this idea, I now explore how the level and growth in new business formation changes following banking reform. ${ }^{19}$

To measure business formation, I use new business incorporations in each state and year from 1976 to 1996 . This series comes from the individual states, as reported and compiled by Dun \& Bradstreet. Business incorporations is not a perfect measure of the rate of business formation in a state, but it offers the best proxy available that is compiled on a consistent basis over a relatively long period. Dun \& Bradstreet also report a series on business "starts" that is an offshoot of their credit database. Since this series goes back only to 1985 , it is not helpful in exploring how the changes in banking that began in the mid-1970s affected entrepreneurship and business formation. ${ }^{20}$ Nevertheless, the starts data can help verify that business incorporations closely tracks the rate of business formation in a state. It turns out that new incorporations per capita and business starts per capita are consistently positively correlated with each other; the cross-state correlation ranged from a low of 0.58 in 1994 to a high of 0.72 in 1988 . There is one important exception, however. The number of incorporations in Delaware is about 20 times the average number of incorporations in the other states (per capita), while the number of starts in Delaware is very close to the average. This difference reflects favorable legal treatment of incorporations in that state. In addition, measures of banking structure in both Delaware and South Dakota are skewed by the presence of credit card banks in those states. We therefore drop both of these states from all of our regressions.

As a further check on the data, incorporations per capita and starts per capita can be compared with the number of new establishments per capita,

\footnotetext{
19 In Black and Strahan (2002), we explore how differences in banking structure across states affect new business formation.

20 Moreover, the starts series depends on a firm's actively seeking to raise funds, because it is based on Dun \& Bradstreet's credit database.
} 


\section{Table 5}

Panel Regression of the Level and Growth in New Incorporations on Banking Deregulation and Employment Share Variables

\begin{tabular}{|c|c|c|c|c|}
\hline \multirow[b]{2}{*}{ Post-branching } & \multicolumn{2}{|c|}{$\begin{array}{l}\text { Log of new } \\
\text { incorporations per capita }\end{array}$} & \multicolumn{2}{|c|}{$\begin{array}{c}\text { Growth of new } \\
\text { incorporations per capita }\end{array}$} \\
\hline & $\begin{array}{c}0.0279 \\
(0.0186)\end{array}$ & $\begin{array}{c}0.0981^{*} \\
(0.0175)\end{array}$ & $\begin{array}{c}0.0312^{*} \\
(0.0128)\end{array}$ & $\begin{array}{c}0.0390^{*} \\
(0.0138)\end{array}$ \\
\hline Post-interstate banking & $\begin{array}{c}0.1169^{*} \\
(0.0243)\end{array}$ & $\begin{array}{c}0.0572^{*} \\
(0.0229)\end{array}$ & $\begin{array}{l}-0.0057 \\
(0.0164)\end{array}$ & $\begin{array}{c}-0.0133 \\
(0.0178)\end{array}$ \\
\hline Share of employment in mining & - & $\begin{array}{r}6.30^{*} \\
(0.92)\end{array}$ & - & $\begin{array}{c}0.75 \\
(0.75)\end{array}$ \\
\hline Share of employment in construction & - & $\begin{array}{c}9.59^{*} \\
(0.70)\end{array}$ & - & $\begin{array}{c}0.42 \\
(0.63)\end{array}$ \\
\hline Share of employment in manufacturing & - & $\begin{array}{l}2.89^{*} \\
(0.69)\end{array}$ & - & $\begin{array}{c}0.52 \\
(0.57)\end{array}$ \\
\hline Share of employment in transportation & - & $\begin{array}{c}6.00^{*} \\
(1.99)\end{array}$ & - & $\begin{array}{c}1.41 \\
(1.59)\end{array}$ \\
\hline Share of employment in trade & - & $\begin{array}{l}6.11^{*} \\
(1.03)\end{array}$ & - & $\begin{array}{c}0.09 \\
(0.83)\end{array}$ \\
\hline Share of employment in finance & - & $\begin{array}{c}6.04^{*} \\
(1.98)\end{array}$ & - & $\begin{array}{c}-2.87^{*} \\
(1.58)\end{array}$ \\
\hline Share of employment in services & - & $\begin{array}{l}2.68^{*} \\
(0.82)\end{array}$ & - & $\begin{array}{c}-0.64 \\
(0.67)\end{array}$ \\
\hline $\mathrm{N}$ & 949 & 890 & 901 & 850 \\
\hline Within $\mathrm{R}^{2}$ & 0.3554 & 0.5166 & 0.1933 & 0.2259 \\
\hline
\end{tabular}

NOTE: Standard errors in parentheses. These regressions are estimated using a fixed-effects model with both year and state effects. The year of deregulation is dropped. Also, South Dakota and Delaware are dropped. * Statistically significant at the 10 percent level.

which is available from the Small Business Administration starting in 1989.21 An establishment is not a firm; rather, it is an economic unit such as a plant, a factory, or a restaurant that employs people. Nevertheless, we think that the number of new establishments ought to be highly correlated with the economic quantity that we are trying to observethe rate of creation of new businesses. Again, it is highly correlated with both incorporations and starts. From 1989 to 1994, the cross-state correlation between incorporations and new establishments ranges from 0.52 to 0.57 , and cross-state correlation between starts and new establishments ranges

\footnotetext{
21 Again, since the new establishments series goes back only to 1989 , it is not useful in exploring the effects of banking deregulation, which was nearing completion by this time.
}

from 0.41 to 0.65 . Thus, new incorporations in a state seems to be a good proxy for new business formation.

Table 3 reports summary statistics for both the level of new incorporations per capita and its annual growth rate. In a typical state and year, there are about 2.5 new incorporations formed for every 1000 people living in a state. The mean growth rate is 2.06 percent per year, slightly higher than the growth in real per capita income. Notice that the variation in the growth of new incorporations is about four times higher than the variation of overall income.

Using the new incorporations data, Table 5 reports how entrepreneurial activity changed following banking deregulation. (Note that in the levels regression, I use the logarithm of the rate of new 
businesses per capita so that the coefficient may be interpreted in percentage terms.) Consistent with the Schumpterian logic, both the level and growth of entrepreneurial activity increased following banking deregulation. The regression coefficients suggest, for example, that the annual level of new incorporations per capita increased by 9.8 percent after branching deregulation and by 5.7 percent after interstate banking reform (column 2). In the specifications using the growth rate, the increase occurred only after branching deregulation. Thus, the effects on entrepreneurial activity of branching deregulation appear to be larger and more persistent than the effects of interstate banking, consistent with the effects of the two reforms on personal income growth. It is also worth noting that the magnitude of the increase in the growth of new incorporations is substantially larger than the increase in personal income growth following reform, although the standard errors are also substantially larger due to the greater variation in this series.

\section{Business Cycle Effects}

The evidence so far points to substantial benefits of opening up banking markets to potential entry and greater competition. Entrepreneurs appear better able to start businesses and, perhaps through their efforts, economic growth accelerates. Crosscountry evidence that is beginning to emerge suggests that opening up financial markets to foreign entry can also create benefits associated with macroeconomic stability (Barth, Caprio, and Levine, 2002). There is some evidence from studies at the bank level, however, that risk-taking may increase with the reductions in franchise value that come following banking deregulation (Keeley, 1990; Demsetz, Saidenberg, and Strahan, 1996; Hellman, Murdock, and Stiglitz, 2000; Bergstresser, 2001).

How did banking reform in the U.S. affect macroeconomic stability? In a recent paper, Morgan, Rime, and Strahan (2002) analyze this question from both a theoretical and an empirical standpoint. They show first that following interstate banking deregulation in the United States, the banking system became substantially better integrated nationally. Prior to deregulation, the U.S. had a balkanized system composed effectively of 50 little banking systems, one for each state. After interstate deregulation, however, an average of about 60 percent of a state's banking assets were owned by a multi-state (or sometimes multinational) banking company. The theoretical effect of this banking integration on business cycles, however, is ambiguous. Morgan, Rime, and Strahan start with a banking model in which bankers can prevent moral hazard-by monitoring firms - as well as commit moral hazard-by neglecting to monitor. These hazards make the equilibrium rate of investment in the economy depend on the level of firm collateral and bank capital; these state variables give firms and bankers a stake in future investment outcomes, but shocks to either variable cause equilibrium investment to fall, i.e., collateral crunches and bank capital crunches are both contractionary.

Morgan, Rime, and Strahan then show how integration of banking - that is, linking up the banking systems of two formerly separate economieschanges the effects of these two kinds of shocks. They show that both collateral and capital shocks remain contractionary after integration, but their magnitudes change: Bank capital shocks become less important after integration, but the effect of collateral shocks gets bigger. The intuition for this result is straightforward and general. A banking company that is diversified across two economies can import capital if lending opportunities in one economy are strong relative to the availability of local bank capital. In contrast, a collateral shock in one economy will lead the integrated bank to export their capital and lending, thus worsening the resulting downturn.

Table 6 quantifies empirically how both branching and interstate banking deregulation affected the magnitude of state business cycles. The dependent variable in these regressions equals the absolute value of the residuals from the personal income growth regressions (Table 4, columns 1 and 3) and the growth in new incorporations regressions (Table 5 , columns 3 and 4). Thus, the dependent variables in Table 6 can be thought of as the magnitude of the deviation from expected growth in state personal income and new businesses, conditional on the employment shares in a state, the state's average growth rate (the state fixed effect), and shocks to the U.S. economy as a whole (the year fixed effects).

The results suggest that overall state-level business cycle volatility fell after interstate banking and the associated financial integration. The coefficients suggest a decline of 0.31 to 0.47 percentage points, which is large relative to the unconditional mean of 1.26 percent (columns 1 and 2). The effects of branching deregulation are not significant, although this should perhaps not be too surprising because branching deregulation allowed integration 


\section{Table 6}

Panel Regression of Volatility of Growth in Real, Per Capita Income and New Incorporations on Banking Deregulation and Employment Share Variables

\begin{tabular}{|c|c|c|c|c|}
\hline \multirow[b]{2}{*}{ Post-branching } & \multicolumn{2}{|c|}{$\begin{array}{c}\text { Volatility in growth in real, } \\
\text { per capita state income }\end{array}$} & \multicolumn{2}{|c|}{$\begin{array}{l}\text { Volatility in growth in new } \\
\text { incorporations per capita }\end{array}$} \\
\hline & $\begin{array}{l}-0.0001 \\
(0.0014)\end{array}$ & $\begin{array}{l}-0.0004 \\
(0.0015)\end{array}$ & $\begin{array}{c}-0.0136 \\
(0.0080)\end{array}$ & $\begin{array}{c}-0.0090 \\
(0.0088)\end{array}$ \\
\hline Post-interstate banking & $\begin{array}{c}-0.0031^{*} \\
(0.0028)\end{array}$ & $\begin{array}{c}-0.0047^{*} \\
(0.0020)\end{array}$ & $\begin{array}{c}-0.0072 \\
(0.0107)\end{array}$ & $\begin{array}{l}-0.0116 \\
(0.0114)\end{array}$ \\
\hline Share of employment in mining & - & $\begin{array}{c}0.01 \\
(0.08)\end{array}$ & - & $\begin{array}{l}1.86^{*} \\
(0.48)\end{array}$ \\
\hline Share of employment in construction & - & $\begin{array}{c}0.20^{*} \\
(0.06)\end{array}$ & - & $\begin{array}{l}0.25 \\
(0.41)\end{array}$ \\
\hline Share of employment in manufacturing & - & $\begin{array}{c}-0.01 \\
(0.06)\end{array}$ & - & $\begin{array}{c}0.24 \\
(0.36)\end{array}$ \\
\hline Share of employment in transportation & - & $\begin{array}{c}0.02 \\
(0.17)\end{array}$ & - & $\begin{array}{c}-2.24^{*} \\
(1.02)\end{array}$ \\
\hline Share of employment in trade & - & $\begin{array}{c}0.08 \\
(0.09)\end{array}$ & - & $\begin{array}{c}0.27 \\
(0.53)\end{array}$ \\
\hline Share of employment in finance & - & $\begin{array}{c}0.20 \\
(0.17)\end{array}$ & - & $\begin{array}{c}1.35 \\
(1.01)\end{array}$ \\
\hline Share of employment in services & - & $\begin{array}{c}0.07 \\
(0.07)\end{array}$ & - & $\begin{array}{c}0.31 \\
(0.43)\end{array}$ \\
\hline $\mathrm{N}$ & 949 & 890 & 901 & 850 \\
\hline Within $R^{2}$ & 0.0650 & 0.0932 & 0.0604 & 0.0987 \\
\hline
\end{tabular}

NOTE: Standard errors in parentheses. The volatility equals the absolute deviation in the growth rate from its expected value-that is, the absolute value of the residuals from the models reported in Tables 4 and 5 . These regressions are estimated using a fixed-effects model with both year and state effects. The year of deregulation is dropped. Also, South Dakota and Delaware are dropped.

*Statistically significant at the 10 percent level.

within a state rather than across state lines. ${ }^{22}$ The results for the volatility of the growth of new incorporations also point in the same direction-toward less volatility following deregulation-although the coefficients on both deregulation indicators are not significant at conventional levels (columns 3 and 4).

The theoretical analysis suggests that the explanation for better macroeconomic stability following deregulation is due to better insulation of a state's economy against shocks to its own banking system. In a disintegrated banking system, such as the one

\footnotetext{
22 Perhaps a better test of the potential stabilizing effects of branching reform would be to use local economic performance, such as from a county or city. Integration of banks within a state might help localities share risks just as integration across state lines help states share risks.
}

we had in the 1970s and early 1980s, shocks to bank capital lead to reductions in lending, thereby worsening the downturn. In contrast, with integration a state can import bank capital from abroad (i.e., from other states) when its banks are down. If this explanation really holds, then the correlation between economic performance and banking performance ought to weaken with deregulation and integration.

Table 7 puts this notion to the test by adding the growth rate of local bank capital to the personal income and incorporations growth regressions reported in Tables 4 and 5, along with interactions between bank capital growth and the deregulation indicator variables. The results provide strong support for the idea that interstate banking deregulation 


\section{Table 7}

\section{Panel Regression of Growth Variables on Banking Deregulation, Bank Capital Growth, and Employment Share Variables}

\begin{tabular}{|c|c|c|c|c|}
\hline \multirow[b]{2}{*}{ Post-branching } & \multicolumn{2}{|c|}{$\begin{array}{l}\text { Growth in real, } \\
\text { per capita state income }\end{array}$} & \multicolumn{2}{|c|}{$\begin{array}{c}\text { Growth in new } \\
\text { incorporations per capita }\end{array}$} \\
\hline & $\begin{array}{c}0.0028 \\
(0.0037)\end{array}$ & $\begin{array}{c}0.0031 \\
(0.0038)\end{array}$ & $\begin{array}{c}0.0238 \\
(0.0202)\end{array}$ & $\begin{array}{c}0.0292 \\
(0.0203)\end{array}$ \\
\hline Post-interstate banking & $\begin{array}{r}0.0099^{*} \\
(0.0041)\end{array}$ & $\begin{array}{l}0.0094^{*} \\
(0.0043)\end{array}$ & $\begin{array}{c}0.0189 \\
(0.0217)\end{array}$ & $\begin{array}{c}0.0244 \\
(0.0226)\end{array}$ \\
\hline Growth in local bank capital & $\begin{array}{c}0.1416 * \\
(0.0234)\end{array}$ & $\begin{array}{c}0.1244^{*} \\
(0.0268)\end{array}$ & $\begin{array}{r}0.4535^{*} \\
(0.1286)\end{array}$ & $\begin{array}{r}0.5388 * \\
(0.1431)\end{array}$ \\
\hline $\begin{array}{l}\text { Growth in local bank capital } \times \\
\text { post-branching }\end{array}$ & $\begin{array}{c}0.0226 \\
(0.0330)\end{array}$ & $\begin{array}{c}0.0322 \\
(0.0348)\end{array}$ & $\begin{array}{c}0.1086 \\
(0.1852)\end{array}$ & $\begin{array}{c}0.1028 \\
(0.1886)\end{array}$ \\
\hline $\begin{array}{l}\text { Growth in local bank capital } \times \\
\text { post-interstate banking }\end{array}$ & $\begin{array}{c}-0.1267^{*} \\
(0.0312)\end{array}$ & $\begin{array}{c}-0.1266^{*} \\
(0.0341)\end{array}$ & $\begin{array}{r}-0.4794^{*} \\
(0.1770)\end{array}$ & $\begin{array}{r}-0.5840^{*} \\
(0.1831)\end{array}$ \\
\hline Employment share variables included? & No & Yes & No & Yes \\
\hline $\mathrm{N}$ & 851 & 794 & 803 & 754 \\
\hline Within $\mathrm{R}^{2}$ & 0.5533 & 0.5881 & 0.2293 & 0.2762 \\
\hline
\end{tabular}

NOTE: Standard errors in parentheses. These regressions are estimated using a fixed-effects model with both year and state effects. The year of deregulation is dropped. Also, South Dakota and Delaware are dropped. *Statistically significant at the 10 percent level. The sample ends in 1994 because the capital growth variable cannot be constructed at the state level accurately after that time.

severed the link between local economic performance and local bank performance. ${ }^{23}$ According to the estimated coefficients, a 10-percentage-point reduction in the growth of bank capital held by local banks would be associated with a decline in personal income growth of 1.2 to 1.4 percent prior to interstate banking reform. After reform, however, this correlation becomes indistinguishable (statistically) from 0 (columns 1 and 2).

Table 7 also shows that the link between local bank capital and the growth of new incorporations is much stronger prior to deregulation, compared with its link with overall income growth, consistent with the premise that banks are especially important for small and young firms. The regression coefficients, for instance, suggest that a 10-percentagepoint reduction in the growth of local bank capital would be associated with a decline in the growth rate of new incorporations of 4.5 to 5.4 percent, again prior to interstate banking reform. After reform, however, this correlation also becomes indistinguishable (statistically) from 0 (columns 3 and 4). So,

\footnotetext{
${ }^{23}$ Local banks here means banks headquartered within the state.
}

integration has salutary effects on business cycles by insulating the local economy from the ups and downs of the local banking system. Of course, the kind of cross-state integration that we experienced following interstate deregulation would not be expected to insulate states from shocks to all banks in the United States.

\section{CONCLUSIONS}

Banking deregulation of restrictions on branching and interstate banking lifted a set of constraints that had prevented better -run banks from gaining ground over their less-efficient rivals. Big changes in the banking industry followed deregulation: many acquisitions and consolidations, integration across state lines, and a decline in the market share of small banks. These changes allowed banks to offer better services to their customers at lower prices. As a result, the real economy- "Main Street" as it were-seems to have benefited. Overall economic growth accelerated following deregulation, and this faster growth seems to have been concentrated among new businesses. Sometimes we think that higher returns necessarily come at the cost of greater 
risk, but in the case of U.S. banking deregulation, volatility of the economy declined as growth went up.

Will these beneficial results on both mean economic growth and business cycle volatility translate over to small economies opening their financial markets? Using a broad panel of countries, Morgan and Strahan (2002) report evidence that foreign bank entry seemed to be followed by more-or certainly no less-economic volatility. But these conclusions are made tentatively; more research is clearly needed. Given the strong statistical results reported here for the United States, it would seem that additional country "case studies" would be particularly valuable.

\section{REFERENCES}

Amel, Dean. "State Laws Affecting the Geographic Expansion of Commercial Banks." Unpublished manuscript, Board of Governors of the Federal Reserve System, 1993.

Barth, James R.; Caprio, Gerald and Levine, Ross. "Bank Regulation and Supervision: What Works Best?” Unpublished manuscript, January 2002.

Bekaert, Geert; Harvey, Campbell R. and Lundblad, Christian T. "Equity Market Liberalization in Emerging Markets." Federal Reserve Bank of St. Louis Review, July/August 2003, 85(4), pp. 53-74.

Berger, Allen N.; Demsetz, Rebecca S. and Strahan, Philip E. "The Consolidation of the Financial Services Industry: Causes, Consequences, and Implications for the Future." Journal of Banking and Finance, February 1999, 23(2-4), pp. 135-94.

Bergstresser, Daniel. "Market Concentration and Loan Portfolios in Commercial Banks." Unpublished manuscript, February 2001.

Black, Sandra E. and Strahan, Philip E. "Entrepreneurship and Bank Credit Availability." Journal of Finance, December 2002, 57(6), pp. 2807-33.

Bonaccorsi di Patti, Emilia and Dell'Ariccia, Giovanni. "Bank Competition and Firm Creation." Working Paper No. 01/21, International Monetary Fund, February 2001.

Cetorelli, Nicola. "Does Bank Concentration Lead to Concentration in Industrial Sectors?" Working Paper No. 2001-01, Federal Reserve Bank of Chicago, March 2001.
"Life-Cycle Dynamics in Industrial Sectors: The Role of Banking Market Structure." Federal Reserve Bank of St. Louis Review, July/August 2003, 85(4), pp. 135-48.

and Gambera, Michele. "Banking Market Structure, Financial Dependence and Growth: International Evidence from Industry Data." Journal of Finance, April 2001, 56(2), pp. 617-48.

Collender, Robert N. and Shaffer, Sherrill L. "Bank Market Structure and Local Employment Growth.” Technical Bulletin No. 1900, United States Department of Agriculture, Economic Research Service, May 2002.

Demirgüç-Kunt, Asli; Levine, Ross and Min, H.G. "Opening to Foreign Banks: Issues of Stability, Efficiency, and Growth." Proceedings of the Bank of Korea Conference on The Implications of Globalization of World Financial Markets. Seoul, Korea: Bank of Korea, December 1998.

Demsetz, Rebecca S.; Saidenberg, Marc R. and Strahan, Philip E. "Banks with Something To Lose: The Disciplinary Role of Franchise Value." Federal Reserve Bank of New York Economic Policy Review, October 1996, 2(2), pp. 1-14.

Djankov, Simeon; La Porta, Rafael; Lopez-de-Silanes, Florencio and Shleifer, Andrei. "The Regulation of Entry." Quarterly Journal of Economics, February 2002, 117(1), pp. 1-37.

Economides, Nicolas; Hubbard, R. Glenn and Palia, Darius. "The Political Economy of Branching Restrictions and Deposit Insurance: A Model of Monopolistic Competition among Small and Large Banks." Journal of Law and Economics, October 1996, 39(2), pp. 667-704.

Freeman, Donald G. "Did State Bank Branching Deregulation Produce Large Growth Effects?" Economics Letters, May 2002, 75(3), pp. 383-89.

Hellman, Thomas; Murdock, Kevin and Stiglitz, Joseph. "Liberalization, Moral Hazard in Banking and Prudential Regulation: Are Capital Requirements Enough?" American Economic Review, March 2000, 90(1), pp. 147-65.

Hubbard, R. Glenn and Palia, Darius. "Executive Pay and Performance: Evidence from the U.S. Banking Industry." Journal of Financial Economics, September 1995, 39(1), pp. 105-30.

Jayaratne, Jith and Strahan, Philip E. "The Finance-Growth Nexus: Evidence from Bank Branch Deregulation.” 
Quarterly Journal of Economics, August 1996, 111(3), pp. 639-70.

and "Entry Restrictions, Industry

Evolution, and Dynamic Efficiency: Evidence from Commercial Banking." Journal of Law and Economics, April 1998, 41(1), pp. 239-73.

Kane, Edward J. "De Jure Interstate Banking: Why Only Now?" Journal of Money, Credit, and Banking, May 1996, 28(2), pp. 141-61.

Keeley, Michael C. "Deposit Insurance, Risk, and Market Power in Banking." American Economic Review, December 1990, 80(5), pp. 1183-200.

King, Robert G. and Levine, Ross. "Finance and Growth: Schumpeter Might Be Right.” Quarterly Journal of Economics, August 1993, 108(3), pp. 717-37.

Kroszner, Randall S. and Strahan, Philip E. "What Drives Deregulation? Economics and Politics of the Relaxation of Bank Branching Restrictions." Quarterly Journal of Economics, November 1999, 114(4), pp. 1437-67.

and "Obstacles to Optimal Policy:

The Interplay of Politics and Economics in Shaping Bank Supervision and Regulation Reforms," in Frederic S. Mishkin, ed., Prudential Supervision: What Works and What Doesn't. Chicago: NBER/University of Chicago, 2001.

La Porta, Rafael; Lopez-de-Silanes, Florencio and Shleifer, Andrei. "Government Ownership of Banks." Journal of Finance, February 2002, 57(1), pp. 265-301.

Levine, Ross. "More on Finance and Growth: More Finance, More Growth?" Federal Reserve Bank of St. Louis Review, July/August 2003, 85(4), pp. 31-46.

; Loayza, Norman and Beck, Thorsten.

"Financial Intermediation and Growth: Causality and
Causes." Journal Of Monetary Economics, August 2000, 46(1), pp. 31-77.

Morgan, Donald P.; Rime, Bertrand and Strahan, Philip E. "Bank Integration and Business Volatility." Unpublished manuscript, May 2002.

and Strahan, Philip E. "Foreign Bank Entry and Business Volatility: Evidence from U.S. States and Other Countries." Unpublished manuscript, November 2002 .

Petersen, Mitchell A. and Rajan, Raghuram G. "The Effect of Credit Market Competition on Lending Relationships," Quarterly Journal of Economics, May 1995, 110(2), pp. 407-43.

Rajan, Raghuram G. and Zingales, Luigi. "Financial Dependence and Growth." American Economic Review, June 1998, 88(3), pp. 559-86.

Robinson, Joan. The Rate of Interest and Other Essays. London: Macmillan, 1952.

Schumpeter, Joseph. The Theory of Economic Development: An Inquiry into Profits, Capital, Interest, and the Business Cycle. Oxford: Oxford University Press, 1951 [reprinted 1969].

Stiroh, Kevin and Strahan, Philip E. "Documentation for Competitive Dynamics of Deregulation: Evidence from U.S. Banking." Journal of Money, Credit, and Banking (forthcoming).

White, Eugene. “The Legacy of Deposit Insurance: The Growth, Spread, and Cost of Insuring Financial Intermediaries," in Michael Bordo, Claudia Goldin, and Eugene N. White, eds., The Defining Moment: The Great Depression and the American Economy in the Twentieth Century. Chicago: University of Chicago Press, 1998. 